Article

\title{
Context-Specific, User-Centred: Designing Urban Green Infrastructure to Effectively Mitigate Urban Density and Heat Stress
}

\author{
Julia Mittermüller ${ }^{1, *, \dagger}$, Sabrina Erlwein ${ }^{2, \dagger}$, Amelie Bauer ${ }^{1}$, Tatjana Trokai ${ }^{2}$, Sophie Duschinger ${ }^{1}$ and Michael \\ Schönemann ${ }^{3}$ \\ ${ }^{1}$ Department of Sociology, Ludwig-Maximilians-Universität in Munich, Germany; E-Mails: j.mittermueller@Imu.de (J.M.), \\ amelie.bauer@soziologie.uni-muenchen.de (A.B.), sophie.duschinger@soziologie.uni-muenchen.de (S.D.) \\ ${ }^{2}$ Chair for Strategic Landscape Planning and Management, Technical University of Munich, Germany; \\ E-Mails: sabrina.erlwein@tum.de (S.E.), tatjana.trokai@tum.de (T.T.) \\ ${ }^{3}$ bifa Environmental Institute, Germany; E-Mail: mschoenemann@bifa.de \\ * Corresponding author \\ † These authors contributed equally to this work
}

Submitted: 22 April 2021 | Accepted: 26 May 2021 | Published: 14 October 2021

\begin{abstract}
Green infrastructure plays a vital role for cities facing the challenges of urbanisation and climate change. It has the potential to mitigate the adverse effects of urban density and the heat island effect, enhancing the ecological and social resilience of cities and their inhabitants. This study identifies contextual, psychological, and social factors which influence people's subjective evaluation of urban green infrastructure (UGI), density, and heat stress. Planning recommendations for effective, context-specific, user-centred design are developed to increase the social and health benefits of UGI in limited space. To do so, a mixed-methods approach that combines social surveys, GIS-analysis, and microclimate modelling was employed. The field studies were undertaken in two contrasting neighbourhoods in Munich, Germany: a densely built and scarcely vegetated inner-city neighbourhood and a declaimed "green and compact" neighbourhood at the outskirts. Both sites are assessed in terms of their supply of green infrastructure, building and population density, and outdoor summer heat loads drawing on geostatistical data and mean radiant temperature modelling. This assessment is compared to the inhabitants' subjective evaluation thereof retrieved from face-to-face questionnaires, and semi-standardised interviews. The results indicate that the existence and the amount of UGI per se are not decisive for people's perception of urban heat, density, and neighbourhood attractiveness. It is rather the perceived accessibility of green spaces, their design, quality, and contextual factors like traffic or the presence of other people that define its value for urban dwellers.
\end{abstract}

\section{Keywords}

crowding; mental maps; neighbourhood quality; outdoor thermal comfort; psychological evaluation; UGI; urban density; urban stress; urban vegetation

\section{Issue}

This article is part of the issue "Towards Green(er) Cities: Contextualizing Green Benefits for Urban Spaces and Contemporary Societies" edited by Juaneé Cilliers (University of Technology Sydney, Australia).

(C) 2021 by the authors; licensee Cogitatio (Lisbon, Portugal). This article is licensed under a Creative Commons Attribution 4.0 International License (CC BY).

\section{Introduction}

Adapting to climate change while addressing increasing housing demands is among the key challenges for growing cities in the fight against urban sprawl (Wolff
\& Haase, 2019). Climate change exacerbates the urban heat island effect (Chapman et al., 2017) and increasing densification is reducing unsealed and green urban areas (Haaland \& van den Bosch, 2015). However, research has shown that urban green infrastructure (UGI) does 
not only lower urban heat levels through shading and evapotranspiration (Bartesaghi Koc et al., 2018) but provides further ecosystem services and enhances social resilience (Bowler et al., 2010; Rall et al., 2017). To exploit the full potential of UGI for residents and enhance adaptation capacities, a context-specific and user-centred design focus is necessary (Hansen \& Pauleit, 2014; Klemm et al., 2017). Therefore, this article explores people's subjective evaluation of UGI in connection with density and heat stress.

\subsection{Perception of Urban Density}

Urban density is a complex phenomenon: In the "compact city" model of the European Commission, a high density of people, jobs, and dwellings is promoted to improve the environmental sustainability and liveability of cities (Commission of European Communities, 1990). Reduced commuter traffic, promotion of public transport, higher social interactions, reduced ground space per capita, and reduced emissions are seen as benefits of high-density cities (Jabareen, 2006). However, critics argue that fresh air, green space supply, and habitats for species are rather provided in lower-density cities (Neuman, 2005), and that a higher cost of land can lead to social inequities (Debrunner et al., 2020). In city planning, urban density mainly refers to building density (height, volume, and spacing) and population density (Cheng, 2010). The term "crowding" is used when density levels are evaluated as too high and a person experiences "sensory and social overload" (Rapoport, 1975, p. 134), a loss of control, or behaviour constraints due to density. Feelings of crowding can occur at very different density levels depending on the (social and material) setting, but also on the individuals themselves and their subjective evaluation of the situation. Cultural, emotional, contextual, and other factors influence whether dense settings are perceived as crowded and result in stressful experiences (Frerichs \& Küpper, 2017; Rapoport, 1975). While certain characteristics of the built environment such as street width (Husemann, 2005), building coverage ratio or block size (Knöll et al., 2018) have been found to increase the feeling of crowding and urban stress, vegetation seems to have a positive effect on the evaluation of density. In a study by Husemann (2005), streets with trees were evaluated as less dense and less crowded than streets without trees. In a participatory study, Kyttä et al. (2013) observed that positively rated urban places had a significantly higher proportion of vegetation than negative ones and a lower building density. The interactions between different aspects of urban form and vegetation and their effects on people's perception of density and crowding still remain rather unclear (Knöll et al., 2018). In this regard, more empiric research focusing on people's evaluation of "real" complex urban environments has been called for to gain a deeper understanding of the dynamics involved.

\subsection{Outdoor Thermal Comfort and Urban Vegetation}

As excessive heat negatively affects human health (Lau et al., 2015), heat stress has become an increasing concern for urban planners, especially against the backdrop of climate change and already elevated urban temperatures (Chapman et al., 2017). Several thermal indices have been developed for the investigation of human thermal comfort, such as physiological equivalent temperature and the universal thermal climate index (Staiger et al., 2019). Microclimatological studies have found that UGI and especially trees can significantly improve human thermal comfort. Large, dense trees reduce daytime air temperature by up to $3^{\circ} \mathrm{C}$ and physiological equivalent temperature directly beneath tree crowns by up to $16^{\circ} \mathrm{C}$ (Lee et al., 2020).

However, findings from environmental psychology suggest that despite being exposed to the same environmental conditions, thermal sensations of people differ (Nikolopoulou \& Steemers, 2003) and that subjective thermal preferences might even contradict physical conditions: Comparing different street designs, Klemm et al. (2015) found that people felt more comfortable in a street with small trees and front gardens than in a street with tall trees, even though the latter showed lower physical heat stress. According to Nikolopoulou and Steemers (2003), the range of psychological factors influencing thermal comfort includes naturalness (degree of artificiality), expectations, former experience, time of exposure, perceived control, and environmental stimulation. Furthermore, the duration of experience influences the thermal perception of a specific site (Klemm et al., 2015). Overall, the psychological impact of urban green spaces on people's perceived thermal comfort remains a relatively unexplored research topic (Klemm et al., 2015).

Thus, this article investigates the interactions between density, heat, and vegetation from a user perspective. By comparing their objective assessment with people's subjective evaluation, we can pinpoint parallels and disparities, exploring factors that influence the perception of the urban environment.

\section{Methodology}

We employed a mixed-methods approach that combines surveys, GIS-analysis, and microclimate modelling to analyse the evaluation of heat, density, and urban vegetation (Figure 2). The field studies were undertaken in two contrasting neighbourhoods in Munich, Germany.

\subsection{Study Areas}

The study site is Munich, one of the fastest-growing and densest German cities (Landeshauptstadt München, 2018). Two contrasting neighbourhoods were selected: a densely-built and sparsely vegetated inner-city neighbourhood (Bahnhofsviertel), and a more sparsely built neighbourhood with ample green infrastructure at the 
outskirts (Messestadt; Figure 1). The Bahnhofsviertel, located directly south of the Munich central station, is not only a transportation hub, but also attracts a diversity of people and businesses. Sporting many small international shops, services, hotels, offices, and several university and medical facilities, the streets are usually bustling with people while at the same time being home to only 5,685 residents. Unlike the Bahnhofsviertel, which has grown and evolved over time, the Messestadt has been planned from scratch as a sustainable residential area on a former airport site at the eastern outskirts of Munich. It was designed in the 1990s with reduced traffic loads, a large landscape park, and is home to 11,895 people from more than 100 nationalities.

\subsection{Objective Evaluation}

\subsubsection{Geostatistical Analysis of Urban Vegetation and Density Parameters}

Urban density was analysed based on the data provided by GeodatenService München (2020) from Munich's official city map (Stadtgrundkarte) using GIS. The floor area ratio was calculated as the total gross floor area (ground floor area multiplied by the number of floors) of all buildings divided by the block area for each city block. As additional parameters for urban density, building coverage (residential/non-residential), traffic areas, and public green space were analysed. Information on the quality of other surfaces (sealed/non-sealed, green/non-green) was obtained from raster data in the European Settlement Map (2017). To determine tree coverage, data on tree cover from satellite data from the Street Tree Layer (2018) were used. Population density (i.e., number of residents) was determined based on $100 \mathrm{~m} \times 100 \mathrm{~m}$ raster data from ZENSUS (2011), as the most current dataset available.

\subsubsection{Modelling of Mean Radiant Temperature With SOLWEIG}

Outdoor human thermal comfort was assessed with the solar flux model SOLWEIG (Lindberg et al., 2018). SOLWEIG has been applied in various microclimatological studies to determine the mean radiant temperature ( $T_{\text {mrt }}$; e.g., Jänicke et al., 2016; Lau et al., 2015). In Central Europe, $T_{m r t}$ is the dominating factor for outdoor human thermal comfort if a cloudless, summer day is considered (Lee \& Mayer, 2018). As a representative for a severely hot day, the 25 th July $2019\left(T_{\max }>30^{\circ} \mathrm{C}\right.$, $\mathrm{T}_{\min }>20^{\circ} \mathrm{C}$, wind speed below $2 \mathrm{~m} / \mathrm{s}$ ) was selected for the simulation study. The required meteorological input data was provided by the Meteorological Institute Munich (2018). Its weather station is located in the city centre of Munich (distance to study areas: $8.7 \mathrm{~km}$ to Messestadt, and $1.7 \mathrm{~km}$ to Bahnhofsviertel). High-resolution digital elevation models, land cover data, and colour-infrared imagery to identify vegetation used for the model set- up were provided by the Bavarian State Office for Survey and Geoinformation (2018). As a compromise between accuracy and modelling time, we set the pixel resolution to $2 \mathrm{~m}$. We analysed the simulation outcomes for $2 \mathrm{pm}$, as this represents the hour with the maximum human heat stress.

\subsection{Subjective Evaluation}

\subsubsection{Questionnaires on Neighbourhood Quality and Public (Green) Spaces}

Face-to-face questionnaires were conducted in both neighbourhoods in July 2019 (Bahnhofsviertel: $n=76$; Messestadt: $n=68$; for detailed sociodemographic information see Table S1 in the Supplementary File). To ensure the representation of a diversity of people, spaces, and atmospheres, the questionnaires were conducted in seven different locations within each neighbourhood (including green spaces, public squares, main and side streets) on all days of the week and at different times of the day. Only warm, sunny days $\left(23-30^{\circ} \mathrm{C}\right)$ were selected for the surveys. In the questionnaire, the participants were presented with a polarity profile, which they were asked to use to describe the neighbourhood (see Figure 5 here and Questionnaire S2 in the Supplementary File). The profile was guided by Kyttä et al. (2013) and based on criteria of applicability and comprehensibility (even for non-residents). Moreover, respondents were asked to spontaneously name places in the neighbourhood that they experienced as pleasant or unpleasant on hot days (free mentions). If respondents were residents of the study area, they were also asked if they would like to participate in an in-depth interview.

\subsubsection{In-Depth Interviews and Mental Mapping}

This way, we were able to recruit a random sample of 28 residents (Bahnhofsviertel: $n=11$, Messestadt: $n=17$ ) for semi-standardised interviews with a duration of 40 to 90 minutes (for sociodemographic characterisation see Table S3 in the Supplementary File). Interviews were recorded, transcribed, and analysed using qualitative data analysis software. The interviews expanded on the answers in the short questionnaire and additionally explored the topics of neighbourhood atmosphere, social cohesion, identification, public (green) spaces, and residential quality. In the interviews, participants were also shown an aerial photograph of their residential area and were encouraged to talk about their everyday activities and mark corresponding routes and locations on the map. To capture thermal comfort conditions in the neighbourhoods' public space, participants marked areas or locations according to their thermal comfort qualities with sticky dots on the map: green dots for places that they generally perceived as pleasant on hot days $\left(>30^{\circ} \mathrm{C}\right)$, red dots for unpleasant ones, and yellow dots for "in between" sensations. In contrast to other ther- 

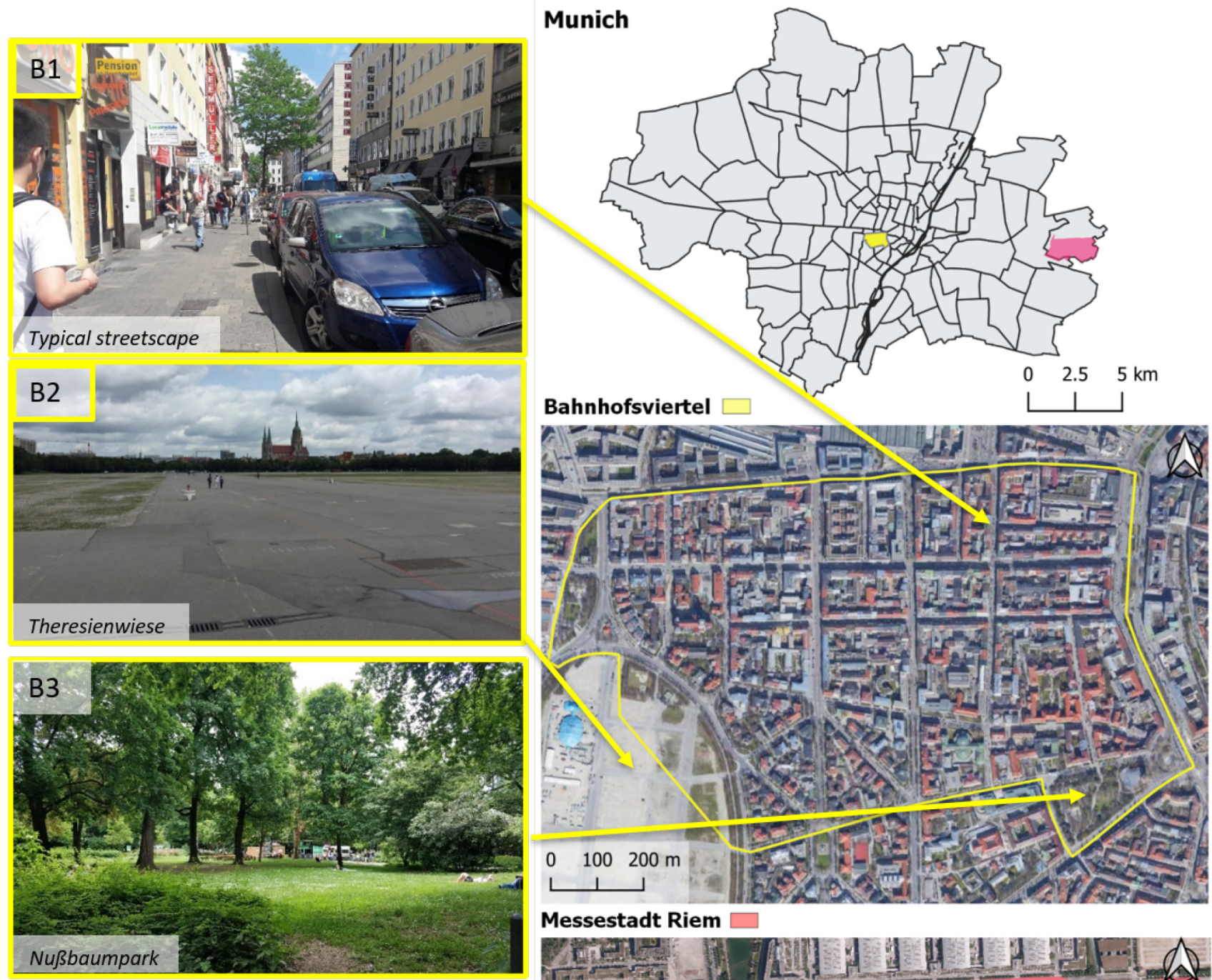

\section{Messestadt Riem $\square$}
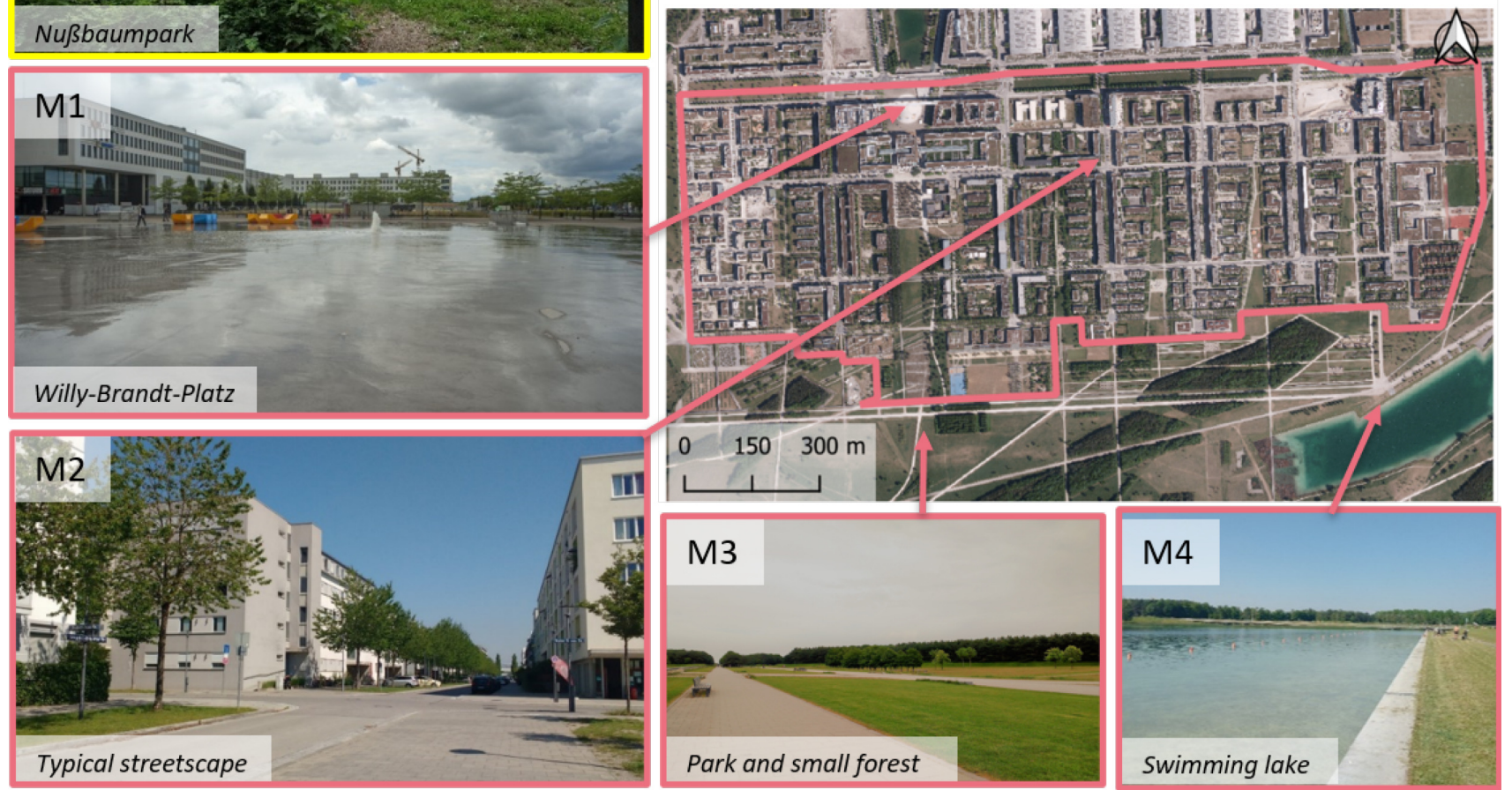

Figure 1. Pictures of distinctive sites of the study areas Bahnhofsviertel (B1-B3) and Messestadt (M1-M4), and their location within Munich. 


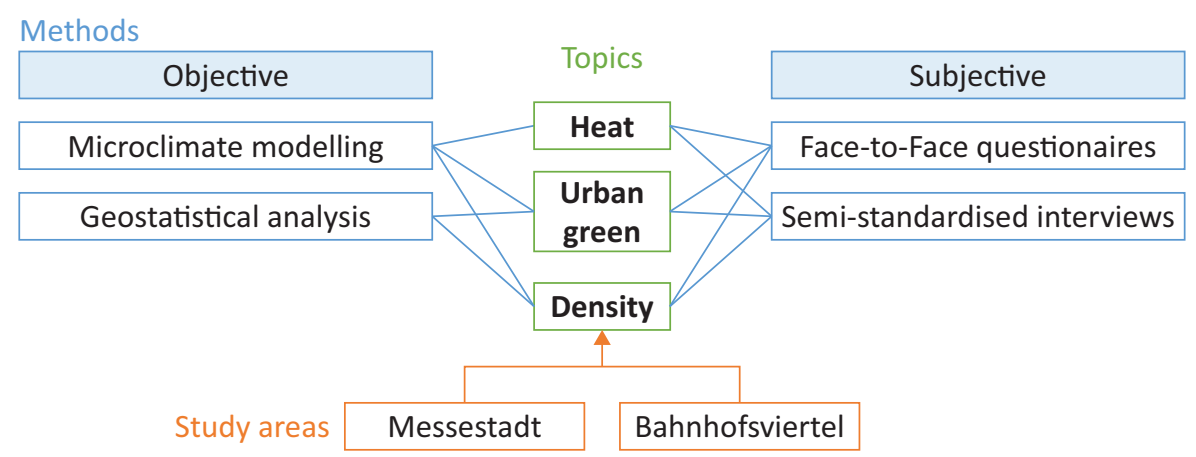

Figure 2. Employed methods and research approach.

mal comfort surveys, which usually focus on right-hereright-now evaluations of current micro-meteorological parameters (like air temperature, sun, humidity, and wind), this mental mapping method allowed us to capture people's long-term memory of holistic thermal perception. All dots were digitised and geocoded using a GIS. Dots referring to larger areas or streets were polygonised. Based on the resulting layers of dots, coloured heat maps were created using Kernel density estimation with a radius of $15 \mathrm{~m}$ (Netek et al., 2018).

\section{Results}

\subsection{Density and Vegetation}

\subsubsection{Objective Assessment of Density and Vegetation}

The study area Bahnhofsviertel consists of 35 building blocks which are dominated by four-storey block perimeter construction of mixed ages. Green infrastructure is scarce in the neighbourhood (11\%; Figure 3). The study area comprises a small park with many trees (see B3 in Figure 1) and part of an open area (B2) which is empty except for events and rimmed by a tree promenade with benches and playgrounds. Within Bahnhofsviertel itself, though, only the southern streets are lined with trees, and backyards are mainly sealed (94.4\%).

Messestadt consists of 48 building blocks featuring mainly three to six-storey apartment buildings (row houses), some perimeter apartment blocks, and some (semi-)detached housing. South of Messestadt is a large park (M3), with a small forest and a swimming lake (M4), connecting the neighbourhood to the surrounding rural zone, only a very small part of which is comprised within the study area. There are several "green links," with playgrounds interlacing the residential area with the park. Although all streets are lined with trees, only tall ones or tree groves appear on the map (Figure 4). Within the residential area, most backyards are green, and buildings on average account for only $43 \%$ of the block surface.

With a floor area ratio of 2.7, Bahnhofsviertel is almost twice as densely built-up as Messestadt with a floor area ratio of 1.4. Despite this, the population density in Bahnhofsviertel is rather low, with 66.3 residents per ha. The opposite is true for the residential district Messestadt, whose population density is 117.7 residents per ha.

\subsubsection{Subjective Evaluation of Density and Vegetation}

As the neighbourhood evaluation shows (polarity profile; Figure 5), the objective assessment of green infrastructure supply and density is well reflected by people's subjective perception. Messestadt is generally perceived as much greener, more relaxed, quiet, and also safer than Bahnhofsviertel, which in turn is rated rather unpleasant, unattractive, and neither bike-, car-, child-, or senior-friendly.

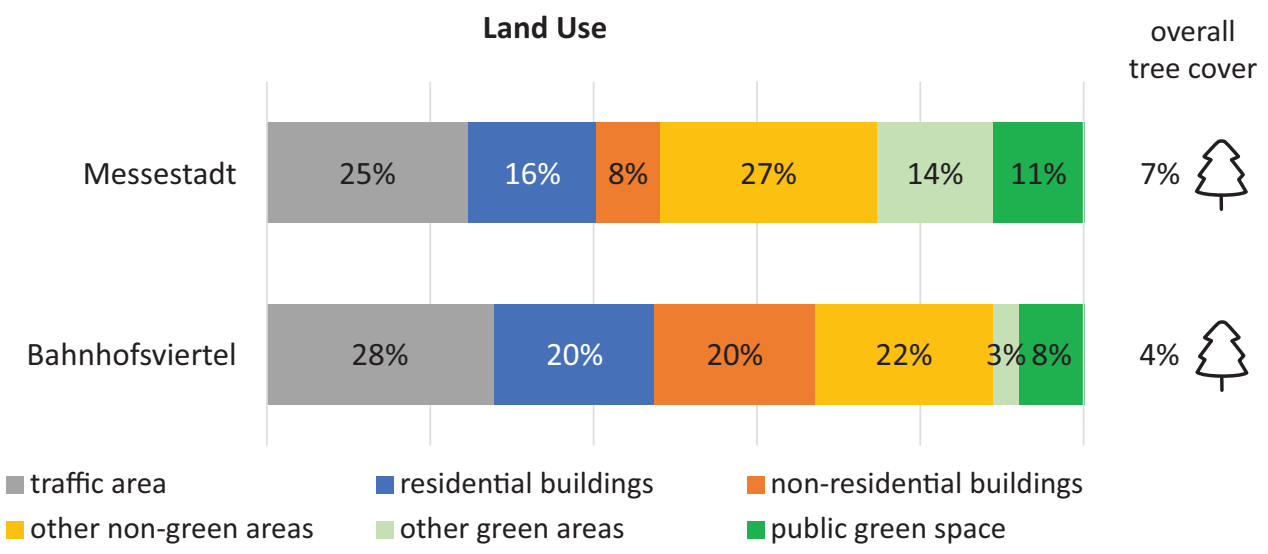

Figure 3. Land use for the study areas of Bahnhofsviertel and Messestadt. 


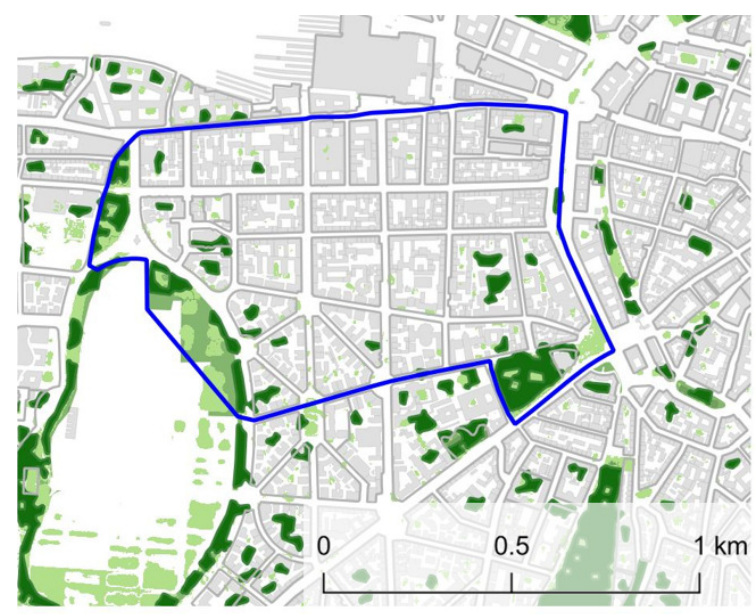

study area buildings

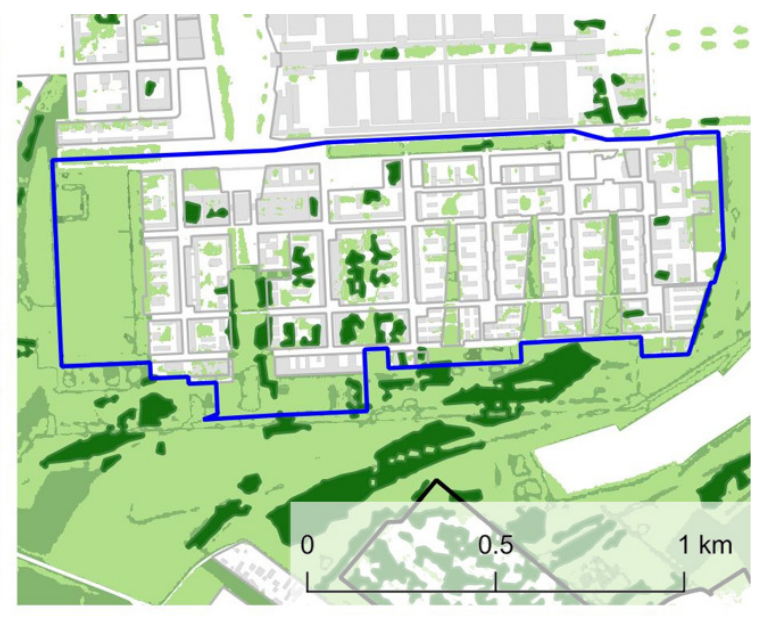

public green space vegetation

Figure 4. Vegetation within and around the study areas of Bahnhofsviertel (left) and Messestadt (right). Sources: treecover from Street Tree Layer (2018), vegetation from European Settlement Map (2017), city structure from GeodatenService München (2020).

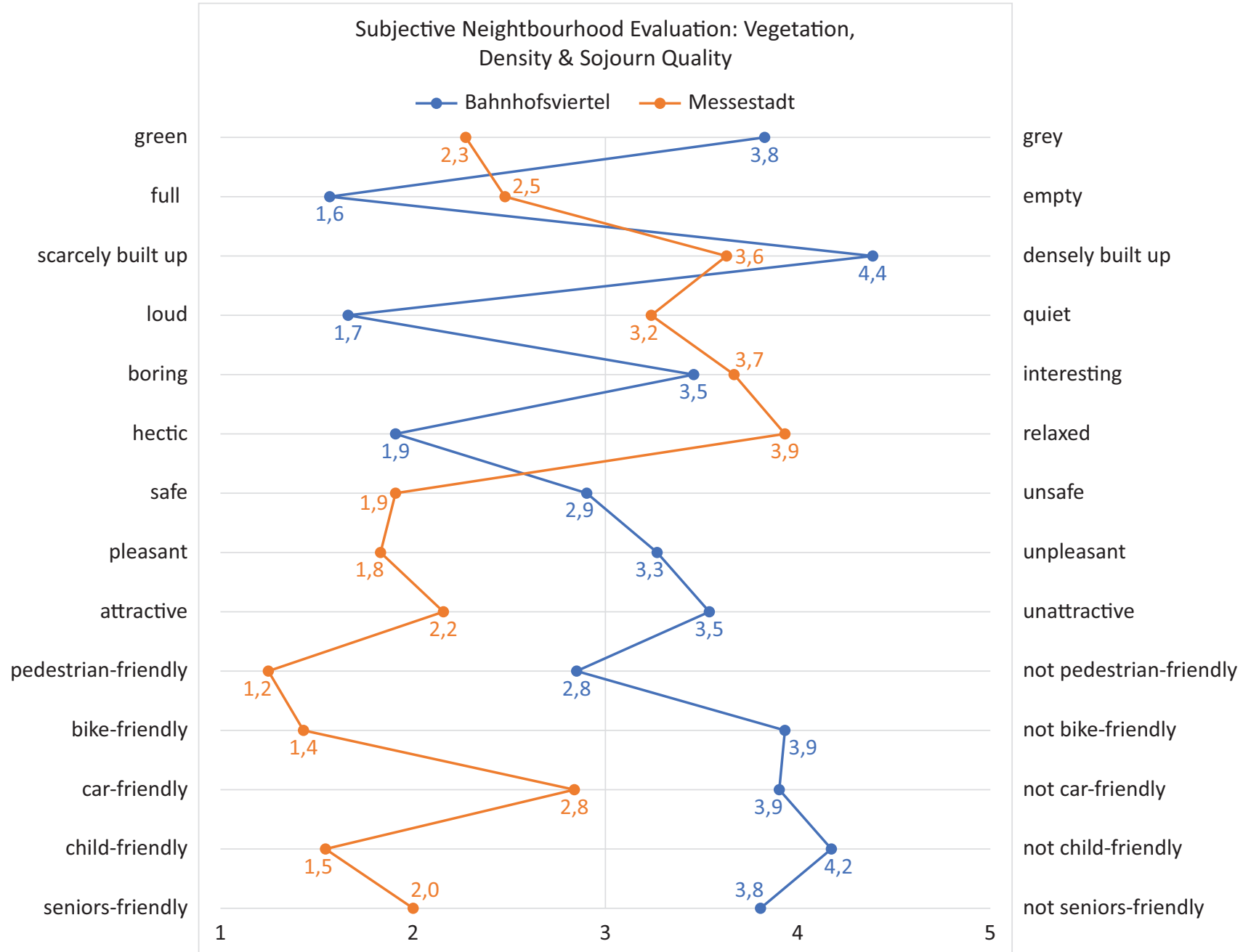

Figure 5. Polarity profile: Subjective evaluation of Bahnhofsviertel (blue) and Messestadt (orange). 
Statistical analysis (Table S4 in the Supplementary File) reveals highly significant correlations between the evaluation of greenness and other items of the polarity profile across both neighbourhoods. Respondents who evaluated their neighbourhood as greener tended to also perceive it as less densely built-up and more pleasant. They also rate their neighbourhood more positively on all other items with the strongest correlations for child- and senior-friendliness, and relaxation. We also found differences regarding the evaluation of density, greenness, and quality of stay between social groups. In both Messestadt and Bahnhofsviertel, residents, in comparison to non-residents, gave "better" ratings for all items except emptiness and safety. Non-native speakers perceived the quarters as less densely built-up and more attractive than native speakers. Also, age seems to make a difference: Participants aged 30 or less generally perceived the neighbourhoods as more pleasant, more relaxed, and-marginally significant-not as densely built-up.

The perceptions of density and vegetation were explored in more detail by the in-depth interviews. This quote by a Bahnhofsviertel resident reflects the general impression of most respondents: "It's brutally dense... every square meter is utilised" (Jürgen, 55). There is noise and bustle on the streets, and especially the heavy car traffic and lack of space contribute to feelings of crowding and stress for many respondents: "Of course, that makes it exhausting sometimes because the streets are crowded, people do what they want, there's crisscross parking in front of the supermarkets and there's no getting through, the sidewalks are full" (Rebecca, 28). However, this density can also be experienced as positive and stimulating: "It's unbelievably narrow, unbelievably dense... everything is quite compact as if you were to press everything together in a ball. Of course, that's also what makes it so appealing, there's an incredible amount of life in it" (Theodor, 51). Street greenery of any kind seems to be the remedy of choice for Bahnhofsviertel residents: "Here [in the southern part of the neighbourhood] it is much greener... when I look out of the window, I could just as well be in the countryside. So that's an enormous relaxation for me..... also think that other people feel less stressed" (Jürgen). The positive psychological effect of vegetation in reducing feelings of crowding and stress is experienced and voiced by almost all respondents: "I think greened streets would definitely help me [to cope]-at least visually" (Micha, 32). One resident, however, voiced objections to planting trees in one of the main streets in the neighbourhood to preserve its historical axis. The large open space Theresienwiese (B2) is an important counterpoint to, and a pleasant relief from, the crowded streets: "When I go grocery shopping, I stop there and sit down. I get to talk to nice people there, but I also find it pleasant in that it's such a wide area. It's soothing to the eye, no advertising" (Rainer, 60). The space's dimensions significantly contribute to its high quality of stay and its function as a social meeting point: "One of my favourite spots is on the steps at the edge of the Theresienwiese, because you simply have this expanse....You take a bottle of wine with you and share it with your friends and look into the distance" (Micha).

In stark contrast to Bahnhofsviertel, in Messestadt there seems to be almost too much space. While the residents appreciate the low building density of their neighbourhood as a pleasant luxury, the street space (M2) is predominantly perceived as large, monotonous, and characterised by a lack of vegetation: "They have extremely wide sidewalks... there is simply far too much paved area" (Martin, 65). Another resident describes, "in fact, that's very brutal if you look along the streets. There are these concrete walls everywhere that separate the front gardens [from the street]. And if they are not greened, then it is simply brutal" (Anke, 47). A woman who has lived in the neighbourhood for many years admits that she sometimes still gets lost because the streets and the "white sterile building blocks" look so similar. Also, Willy-Brandt-Platz (M1), a large open square at the entrance to Messestadt is perceived by almost all respondents as far too big: "That's the main problem. The square is much, much too big for its function. It has no function" (Thomson, 45). Most would prefer greening the square with planters, arbours, or climbing plants that "would kind of make the space not seem so infinite" (Gertrud, 66). Interestingly, in Messestadt feelings of crowding are only experienced in the park, more precisely at the swimming lake (M4), which is "a people magnet." Most interviewees feel very much attached to "their lake," which, to them, is the biggest asset of the neighbourhood. It serves important social functions, especially for teenagers: "Apart from the lake, there's really no such thing as a real place for me to stay away from home" (Leopold, 14). The remaining "empty" space of the 210-ha park, however, is heavily underused: "On the meadows, there is hardly anyone....I think one prefers sitting down at a lake to somewhere where there is nothing" (Darian, 48). One teenager even suspects that "you are not allowed to go into the meadows" (Leopold). The "generous" supply of (semi-)private green space (e.g., backyards and gardens) further decreases residents' need to use the public park.

In summary, the street space in Bahnhofsviertel is perceived as narrow and crowded, while in Messestadt streets and sidewalks are very wide and the same time experienced as rather empty. Public spaces in both neighbourhoods seem to have a rather low quality of stay, though for contrasting reasons. In Bahnhofsviertel, this is mainly due to heavy car traffic, feelings of crowding, or lack of safety; in Messestadt, it is more due to the missing street life and poor architectural design, which is considered "boring." A key factor in both cases is the perceived lack of vegetation which people seem to crave as relief from both too much and not enough urban density. In high-density settings, street greenery can create an atmosphere of relaxation and can bring relief from 
sensory overload. Where density is too low, vegetation can create a comfortable feeling of enclosure and can be a stimulating visual variation.

\subsection{Heat Load and Vegetation}

\subsubsection{Objective Assessment of Heat Load and Vegetation}

In both neighbourhoods, the most uncomfortable areas with the highest $T_{m r t}$ values at $2 \mathrm{pm}$ are found in locations without shade (Figure 6). Thorsson et al. (2014) proposed a threshold of $55^{\circ} \mathrm{C}$ for elevated and $59.4^{\circ} \mathrm{C}$ for extreme heat stress. Open spaces (B2, M1) and nonshadowed $\mathrm{N}-\mathrm{S}$ running streets depict $\mathrm{T}_{\text {mrt }}$ values of $64^{\circ} \mathrm{C}$ and more. As the building structure in Messestadt is less compact than in Bahnhofsviertel, a larger fraction of the study area falls into the extreme heat stress category due to lack of shade (average $\mathrm{T}_{\text {mrt }}$ of $60.1^{\circ} \mathrm{C}$ for Messestadt, $56.4^{\circ} \mathrm{C}$ for Bahnhofsviertel). The most comfortable areas in both neighbourhoods are located in the shade of trees and buildings ( $T_{\text {mrt }}$ values from $35-40^{\circ} \mathrm{C}$ ). The small forest in Messestadt M3 (mean $\mathrm{T}_{\text {mrt }} 35-37^{\circ} \mathrm{C}$ ), the park in Bahnhofsviertel B3 (mean
$\mathrm{T}_{\mathrm{mrt}} 39-40^{\circ} \mathrm{C}$ ), but also single street trees provide significantly reduced heat loads for residents. Heat loads and cool spots are not evenly distributed across the study areas. In Bahnhofsviertel, the north has higher heat exposure due to the absence of trees. In Messestadt, walkways and the southern meadows (M3) are exposed to heat and thermally uncomfortable.

\subsubsection{Subjective Evaluation of Heat Exposure and Vegetation}

The subjective heat maps (Figure 6) show that the most comfortably rated places coincide very well with the existing tree stock, whereas the open spaces and almost all streets are perceived as uncomfortable on hot days. This general observation coincides very well with the modelled thermal comfort. In Bahnhofsviertel, more than half of all respondents named "streets" as the most uncomfortable places, followed by the central station $(17.1 \%)$ and the whole neighbourhood in general (7.9\%; Table 1). Heat stress is highest where high density and lack of vegetation are combined with other heat exacerbating factors, like exhaust fumes. Feelings of crowding and perceived heat stress mutually reinforce
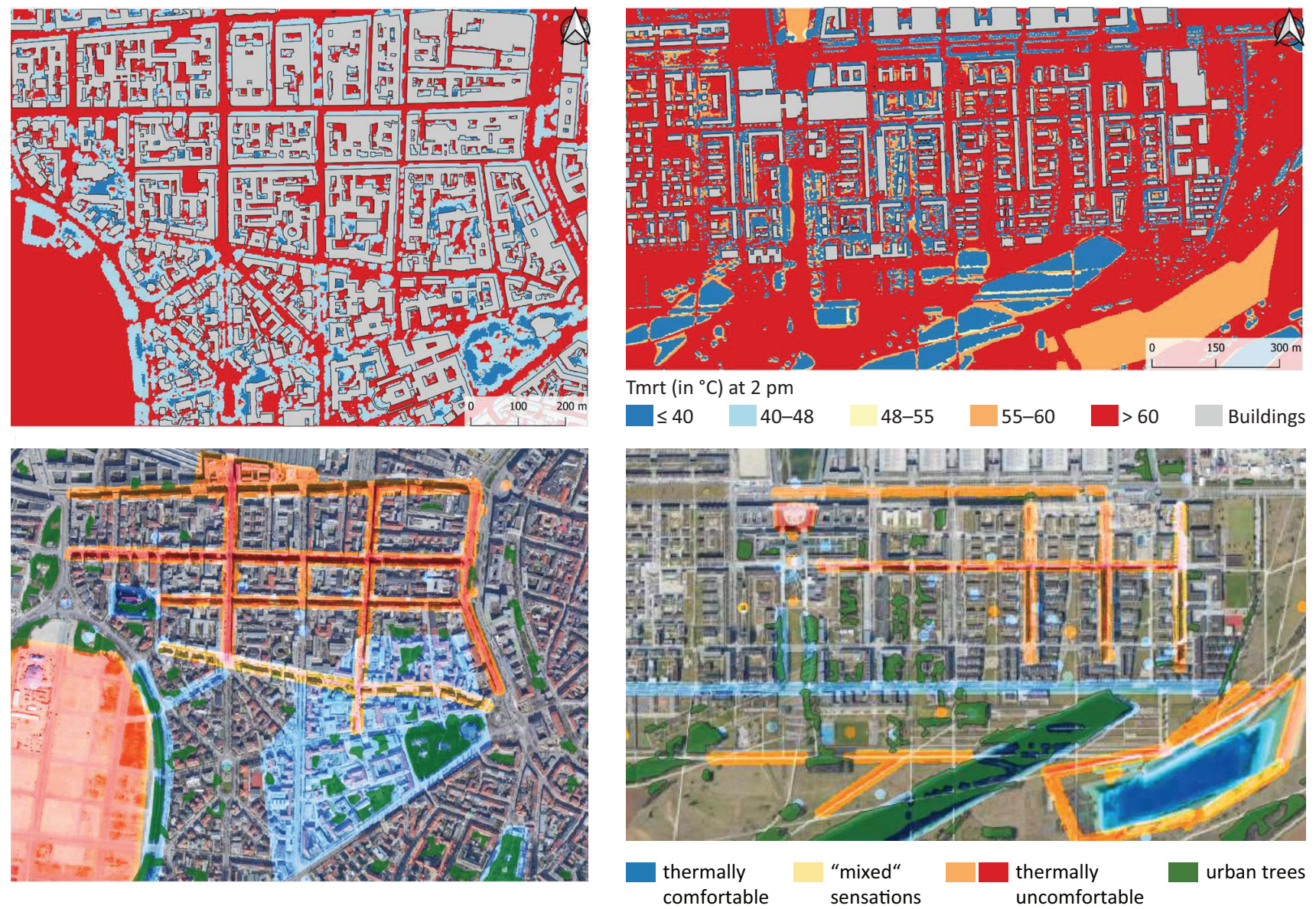

Figure 6. $T_{\text {mrt }}$ model results for 25th July 2019 at 2 pm (top) and perceived thermal comfort maps (bottom) for Bahnhofsviertel (left) and Messestadt (right). The colour intensity in the subjective heat maps reflects the number of times the area or location was mentioned. 
Table 1. Top three comfortable (left) and uncomfortable (right) sites in hot weather in each neighbourhood.

\begin{tabular}{|c|c|c|c|}
\hline \multicolumn{2}{|c|}{$\begin{array}{l}\text { Messestadt: Top Three Sites } \\
\text { Thermal Comfort }(n=68)\end{array}$} & \multicolumn{2}{|c|}{$\begin{array}{l}\text { Messestadt: Top Three Sites } \\
\text { Thermal Discomfort }(n=68)\end{array}$} \\
\hline Swimming lake M4 & $54.4 \%$ & Willy-Brandt-Square M1 & $25.0 \%$ \\
\hline Home/Private garden & $30.8 \%$ & Streets (in general) M2 & $23.5 \%$ \\
\hline Shopping mall & $19.1 \%$ & Park M3 & $10.3 \%$ \\
\hline
\end{tabular}

Bahnhofsviertel: Top Three Sites

Thermal Comfort $(n=76)$

\begin{tabular}{lr}
\hline Theresienwiese (area) B2 & $11.8 \%$ \\
Nußbaumpark B3 & $10.5 \%$ \\
Fountains & $7.9 \%$
\end{tabular}

Bahnhofsviertel: Top Three Sites

Thermal Discomfort $(n=76)$

Streets (in general) B1

$51.3 \%$

Central station

$17.1 \%$

Whole neighbourhood each other: "[This street] is such a narrow canyon of houses, or maybe I perceive it as much narrower on such a hot day" (Rebecca). The neighbourhood's compact building structure and narrow streets are, thus, a blessing and a curse at the same time. Narrow streets and tall buildings reduce sun exposure, while wider streets allow for the experience of cool winds and relief from crowded situations. This is also why the large open square Theresienwiese (B2) is the most frequently mentioned of comfortable places in Bahnhofsviertel (11.8\%). However, in hot weather, people's use of the area concentrates at the partly tree-lined edges of the square. The Nußbaumpark (B3) was named most comfortable by $10.5 \%$ of respondents, followed by fountains in different locations (7.9\%).

Conversely, in Messestadt, the site most often mentioned as uncomfortable in hot weather is the large open square Willy-Brandt-Platz (M1; 25\%). "Streets" (M2) were named by $23.5 \%$ of respondents, followed by the public park (M3; 10.3\%), and sports or playgrounds (7.3\%). The experience of thermal discomfort in all these places is mainly attributed to a lack of shading trees. Existing trees are perceived as too small or even "puny" and the combination of street and building design reinforces heat stress: "Well, I think that the fact that there are so many white, large houses makes them very radiant. I definitely miss green there" (Maria, 22). One notable exception is a promenade that runs E-W and is lined with tall trees. Several interviewees related that this was always the road they chose on hot days, even if that meant taking a diversion. Notably, people experience heat stress even (and especially) in the park, mainly on the paths (M3), but also around the swimming lake (M4), because there is not enough shade. Nevertheless, the swimming lake is the place most frequently mentioned as pleasant on hot days (54.4\%) and is also the only public outdoor space among the top three in the neighbourhood.

In both neighbourhoods, some places are shaded by trees and exhibit low levels of (subjective and objective) heat exposure but whose cooling function is neither used nor appreciated by most people because of their poor quality of stay. The park in Bahnhofsviertel (B3) is rated as a cool place on hot days; however, it is rarely used at all by respondents. Only $27.6 \%$ sometimes go there and only $14.5 \%$ of all respondents like spending time there. A resident of Bahnhofsviertel explains: "Why should I go there?... I wouldn't use the park... even though it is green, there is just not the atmosphere for me to relax like in a park" (Jürgen). One woman who lives in Bahnhofsviertel describes her feeling about the park as uncomfortable due to the design which is dominated by a lot of old trees and little open space: "Somehow, everything is so dark there. The paths cross each other, it's so opaque, for me there's just such a darkness attached to it that I really don't feel comfortable there and I actually even avoid it during the day" (Rebecca). Other interviewees refer to socially marginalised groups and alcohol and drug use in the park, which makes it unattractive for them. Most interviewees prefer visiting other, more attractive, green spaces instead and do not mind taking on longer journeys to get there. Likewise, in Messestadt, there is a tree-covered public square with some benches, which is evaluated as cool on hot days but is visited only infrequently: "In theory, there is shade, but it is just not comfortable there. I have never felt the impulse to sit down there," says Gertrud. Similarly, the small forest in the park could serve its function as a cool oasis amidst the heat-exposed grasslands if it were not considered hardly accessible, making it "a place for dogs rather than for people to stay" (Maria).

In summary, the perception of heat stress in both neighbourhoods is influenced most by the supply or lack of shade, especially natural shade by trees. While there is no space for greenery in Bahnhofsviertel, the trees in Messestadt are too small to provide effective shade. Hence, in both neighbourhoods, streets, and most other public spaces are perceived as hot and uncomfortable in summer. This observation corresponds well with the simulation results. Not quite in accordance with the simulation, both parks and potential cool islands do not seem to play a crucial role in individual heat stress 
adaptation, as their design does not meet users' criteria. Also, Bahnhofsviertel is considered much more uncomfortable in hot weather than Messestadt, which is not supported by the simulation outcomes. This disparity is likely caused by traffic, people density, and visual building characteristics, which clearly influence people's heat perception, but have not been regarded in the objective heat assessment. Again, vegetation seems to have a positive impact on people's perception of heat that goes beyond its simulated cooling effect. We suggest that due to previous experiences and people's general knowledge that plants and trees provide shade and coolness, visual stimuli can provoke those very sensations. The same effect occurs with water. Where urban vegetation is scarce, water takes on an important cooling function, even if it is not "used" in a strict sense. Blue infrastructure (in our cases the lake and the fountains) seems to be able to compensate for the lack of green infrastructure, to some extent (Figure 7).

\section{Discussion and Planning Implications}

Our results support the idea that urban vegetation not only reduces objective heat loads but also reduces feelings of crowding and increases (thermal) well-being. This is in line with other studies that have found positive psychological effects of vegetation for thermal comfort (Klemm et al., 2015; Nikolopoulou \& Steemers, 2003), urban stress (Kabisch et al., 2021; Knöll et al., 2018), and health (Kondo et al., 2018).

Depending on the density context, large open public (green) spaces can create an uncomfortable atmosphere of desolation or pleasant sensations of spaciousness and relaxation. Our results indicate that vegetation enhances the quality of stay in low-density settings, which to our knowledge has not yet been investigated in detail and is worth further research. Large open spaces or wide streets in low-density neighbourhoods were often perceived as uncomfortable, which is supported by other studies like Knöll et al.'s (2018), or Kaspar and Bühler's (2009), who found that visual openness is related to higher perceived urban stress and relate it to feelings of exposure. In such sites, vegetation or even additional construction could supply shade and foster feelings of enclosure by creating intimate, small-scale public spaces with a varied and stimulating design.

In our study, building density, as the most popular indicator for density in urban planning, seems to have less effect on perceived heat stress and crowding in public than traffic, or people density. Tall buildings and narrow streets can increase daytime thermal comfort by providing shaded walkways while motorised but also stationary traffic exacerbates heat stress and crowding. Though limited solar access on the streetscape is beneficial during summertime, it increases thermal discomfort during the cold season. Moreover, less compact structures are beneficial for ventilation and nocturnal cooling, as open spaces foster out-going long-wave radiation and turbulent heat exchange (Onomura et al., 2016). This means that decoupling different forms of density can be a highly effective lever to reduce both crowding and heat stress. Where building density is high, we therefore recommend making traffic reduction and walkability a central concern for improvement. The importance of the general attractiveness and appreciation of a place for thermal comfort perception is also highlighted by other research (Lemonsu et al., 2019). Creating space for street trees, e.g., at the expense of parking space, enhances the quality of stay and decreases heat stress and crowding. Deciduous trees are advantageous since they provide shade in the summertime and solar access in winter. In narrow streets, where planting of trees might be impossible and would block ventilation, we, therefore, recommend using visual green elements at eye level (e.g., green facades, shrubs, or planters) to increase the "naturalness" of stressful urban settings, since our results showed positive psychological benefits achieved by urban greenery.

Wherever possible, places to rest combined with vegetation and (natural) shade should be made available, especially for residents with reduced mobility. If greened and made accessible, backyards and roofs bear great potential as high-quality (semi-)public spaces in high-density settings. Our findings support the idea that, in contrast to qualitative factors, building heights "play a relatively small role explaining perceived urban

Main results

\begin{tabular}{|c|c|c|}
\hline Objective & Urban Heat - Thermal Comfort & Subjective \\
\hline $\begin{array}{l}\text { Microclimate } \\
\text { modelling }\end{array}$ & $\begin{array}{l}\text { - Divergence due to traffic, people density, } \\
\text { and wind } \\
\text { - Tree shade and water most comfortable }\end{array}$ & Interviews \& \\
\hline $\begin{array}{c}\text { Geostatistical } \\
\text { analysis }\end{array}$ & $\begin{array}{l}\text { Urban Density -Crowding } \\
\text { - Building density less influential than traffic } \\
\text { density and atmosphere }\end{array}$ & $\begin{array}{l}\text { Face-to-face } \\
\text { questionaires }\end{array}$ \\
\hline & - Positive psychological effect of greenery & \\
\hline
\end{tabular}

Figure 7. Summary of interaction and main results of the mixed-methods study. 
stress" (Knöll et al., 2018, p. 805), while views into the distance are highly valued characteristics, especially among residents of dense neighbourhoods. This suggests that re-densification projects which combine additional storeys with a corresponding redesign of roof areas could result in added value for residents and increased acceptance. As we have seen, urban vegetation is crucial for reducing perceived heat stress, with tall trees providing the most substantial cooling effect. However, the full potential of parks or tree-covered squares for individual heat stress adaptation depends on their accessibility and attractiveness and can only be exploited if set in the right context. Studies by Kyttä et al. (2013) or Klemm et al. (2015) equally highlight that the quality of green space is more important than the quantity. Suburban residents seem to be more selective concerning their use of public space and do not seek peace and quiet to the same degree as residents of dense and highly stimulating neighbourhoods. Also, younger people and people with different cultural backgrounds tend to be more tolerant towards urban density and sensory overload than older citizens. Thus, public parks fulfil different functions in low- and high-density settings, also depending on the amount of private (green) space available and have to be designed bearing in mind the respective requirements of their residents.

In conclusion, our study has shown that the assessment of density parameters and thermal layout does not provide enough information to adequately balance conflicting objectives concerning the use of public urban space. The assessment has to be supplemented by local knowledge to determine the value of these spaces for residents and, thus, their meaning for the ecological and social resilience of cities and their inhabitants (Frerichs \& Küpper, 2017). Effective, context-specific, user-centred design of green spaces can increase social and health benefits of UGI in neighbourhoods with different densities.

\section{Acknowledgments}

This study was carried out within the project "Grüne Stadt der Zukunft-Klimaresiliente Quartiere in einer wachsenden Stadt" ("Future Green City"), with financial support from the Federal Ministry of Education and Research (BMBF, Germany). Special thanks are due to Kerstin Burkhart and Marco Giardino, whose bachelor and master thesis contributed to the objective heat assessment of the two study sites.

\section{Conflict of Interests}

The authors declare no conflict of interests.

\section{Supplementary Material}

Supplementary material for this article is available online in the format provided by the authors (unedited).

\section{References}

Bartesaghi Koc, C., Osmond, P., \& Peters, A. (2018). Evaluating the cooling effects of green infrastructure: A systematic review of methods, indicators and data sources. Solar Energy, 166, 486-508. https://doi.org/ 10.1016/j.solener.2018.03.008

Bavarian State Office for Survey and Geoinformation. (2018). Digital orthopoto, digital terrain model, digital terrain model and house perimeters of Bahnhofsviertel Munich [Unpublished data]. Munich.

Bowler, D. E., Buyung-Ali, L., Knight, T. M., \& Pullin, A. S. (2010). Urban greening to cool towns and cities: A systematic review of the empirical evidence. Landscape and Urban Planning, 97(3), 147-155. https://doi.org/ 10.1016/j.landurbplan.2010.05.006

Chapman, S., Watson, J. E. M., Salazar, A., Thatcher, M., \& McAlpine, C. A. (2017). The impact of urbanization and climate change on urban temperatures: A systematic review. Landscape Ecology, 32(10), 1921-1935. https://doi.org/10.1007/s10980-0170561-4

Cheng, V. (2010). Understanding density and high density. In E. Ng (Ed.), Designing high-density cities for social and environmental sustainability (pp. 4-17). Routledge.

Commission of European Communities. (1990). Green paper on the urban environment-Communication from the commission to the council and the parliament (EUR 12902).

Debrunner, G., Hengstermann, A., \& Gerber, J.-D. (2020). The business of densification: Distribution of power, wealth and inequality in Swiss policy making. Town Planning Review, 91(3), 259-281. https://doi.org/ 10.3828/tpr.2020.15

European Settlement Map. (2017). European settlement map 2012-Release 2017. Institute for Protection and Security of the Citizen-European Commission Joint Research Centre. https://land.copernicus.eu/ pan-european/GHSL/european-settlement-map/ esm-2012-release-2017-urban-green

Frerichs, S., \& Küpper, C. (2017). Umwelt- und Aufenthaltsqualität in kompakt-urbanen und nutzungsgemischten Stadtstrukturen. Analysen, Fallbeispiele, Handlungsansätze unter Nutzung und Weiterentwicklung des Bauplanungs- und Umweltrechts. Umweltbundesamt [Environmental quality and quality of stay in compact and mixed-use urban structures: Analyses, case studies, approaches to action using and further developing construction planning and environmental law]. Umweltbundesamt. https://www.umweltbundesamt.de/sites/default/ files/medien/1410/publikationen/2018-01-29_ texte_06-2018_stadtstrukturen.pdf

GeodatenService München. (2020). Geoinformationsdaten der Stadtgrundkarte [Geodata from the official city map of Munich]. Geodata-Service Municipal Department of Munich. 
Haaland, C., \& van den Bosch, C. K. (2015). Challenges and strategies for urban green-space planning in cities undergoing densification: A review. Urban Forestry \& Urban Greening, 14(4), 760-771. https:// doi.org/10.1016/j.ufug.2015.07.009

Hansen, R., \& Pauleit, S. (2014). From multifunctionality to multiple ecosystem services? A conceptual framework for multifunctionality in green infrastructure planning for urban areas. AMBIO, 43(4), 516-529. https://doi.org/10.1007/s13280-014-0510-2

Husemann, A. (2005). Die Wahrnehmung und Bewertung von verdichteten Stadtquartieren [The perception and evaluation of dense neighbourhoods]. Tenea.

Jabareen, Y. R. (2006). Sustainable urban forms. Journal of Planning Education and Research, 26(1), 38-52. https://doi.org/10.1177/0739456x05285119

Jänicke, B., Meier, F., Lindberg, F., Schubert, S., \& Scherer, D. (2016). Towards city-wide, building-resolving analysis of mean radiant temperature. Urban Climate, 15, 83-98. https://doi.org/10.1016/j.uclim.2015.11.003

Kabisch, N., Püffel, C., Masztalerz, O., Hemmerling, J., \& Kraemer, R. (2021). Physiological and psychological effects of visits to different urban green and street environments in older people: A field experiment in a dense inner-city area. Landscape and Urban Planning, 207, Article 103998. https://doi.org/10.1016/ j.landurbplan.2020.103998

Kaspar, H., \& Bühler, E. (2009). Planning, design and use of the public space Wahlenpark (Zurich, Switzerland): Functional, visual and semiotic openness. Geographica Helvetica, 64(1), 21-29. https://doi.org/10.5194/ gh-64-21-2009

Klemm, W., Heusinkveld, B. G., Lenzholzer, S., \& van Hove, B. (2015). Street greenery and its physical and psychological impact on thermal comfort. Landscape and Urban Planning, 138, 87-98. https://doi.org/ 10.1016/j.landurbplan.2015.02.009

Klemm, W., van Hove, B., Lenzholzer, S., \& Kramer, H. (2017). Towards guidelines for designing parks of the future. Urban Forestry \& Urban Greening, 21, 134-145. https://doi.org/10.1016/j.ufug.2016. 11.004

Knöll, M., Neuheuser, K., Cleff, T., \& Rudolph-Cleff, A. (2018). A tool to predict perceived urban stress in open public spaces. Environment and Planning B: Urban Analytics and City Science, 45(4), 797-813. https://doi.org/10.1177/0265813516686971

Kondo, M., Fluehr, J., McKeon, T., \& Branas, C. (2018). Urban green space and its impact on human health. International Journal of Environmental Research and Public Health, 15(3), Article 445. https://doi.org/ 10.3390/ijerph15030445

Kyttä, M., Broberg, A., Tzoulas, T., \& Snabb, K. (2013). Towards contextually sensitive urban densification: Location-based soft GIS knowledge revealing perceived residential environmental quality. Landscape and Urban Planning, 113, 30-46. https://doi.org/ 10.1016/j.landurbplan.2013.01.008
Landeshauptstadt München. (2018). Langfristige Siedlungsentwicklung-Zweiter Statusbericht. Sitzungsvorlagen Nr. 14-20/V 12595 [Long-term settlement development-Second status report. Session Papers No. 14-20/V 12595]. https://www.muenchen.de/ rathaus/Stadtverwaltung/Referat-fuer-Stadtplanungund-Bauordnung/Projekte/Langfristige-

Siedlungsentwicklung/Naechste-Schritte.html

Lau, K. K.-L., Lindberg, F., Rayner, D., \& Thorsson, S. (2015). The effect of urban geometry on mean radiant temperature under future climate change: A study of three European cities. International Journal of Biometeorology, 59(7), 799-814. https://doi. org/10.1007/s00484-014-0898-1

Lee, H., \& Mayer, H. (2018). Maximum extent of human heat stress reduction on building areas due to urban greening. Urban Forestry \& Urban Greening, 32, 154-167. https://doi.org/10.1016/j.ufug.2018.04. 010

Lee, H., Mayer, H, \& Kuttler, W. (2020). Impact of the spacing between tree crowns on the mitigation of daytime heat stress for pedestrians inside E-W urban street canyons under Central European conditions. Urban Forestry \& Urban Greening, 48, https://doi. org/10.1016/j.ufug.2019.126558

Lemonsu, A., Amossé, A., Chouillou, D., Gaudio, N., Haouès-Jouve, S., Hidalgo, J., Le Bras, J., Legain, D., Marchandise, S., \& Tudoux, B. (2019). Comparison of microclimate measurements and perceptions as part of a global evaluation of environmental quality at neighbourhood scale. International Journal of Biometeorology, 64(2), 265-276. https://doi.org/10.1007/ s00484-019-01686-1

Lindberg, F., Grimmond, C. S. B., Gabey, A., Huang, B., Kent, C. W., Sun, T., Theeuwes, N. E., Järvi, L., Ward, H. C., Capel-Timms, I., Chang, Y., Jonsson, P., Krave, N., Liu, D., Meyer, D., Olofson, K. F. G., Tan, J., Wästberg, D., Xue, L., \& Zhang, Z. (2018). Urban multiscale environmental predictor (UMEP): An integrated tool for city-based climate services. Environmental Modelling \& Software, 99, 70-87. https://doi.org/ 10.1016/j.envsoft.2017.09.020

Netek, R., Pour, T., \& Slezakova, R. (2018). Implementation of heat maps in geographical information system-Exploratory study on traffic accident data. Open Geosciences, 10(1), 367-384. https://doi.org/ 10.1515/geo-2018-0029

Neuman, M. (2005). The compact city fallacy. Journal of Planning Education and Research, 25(1), 11-26. https://doi.org/10.1177/0739456x04270466

Nikolopoulou, M., \& Steemers, K. (2003). Thermal comfort and psychological adaptation as a guide for designing urban spaces. Energy and Buildings, 35(1), 95-101. https://doi.org/10.1016/S03787788(02)00084-1

Meteorological Institute Munich. (2018). Weather data station Munich summer 2015 [Unpublished raw data]. Ludwigs-Maximilian-University Munich. 
Onomura, S., Holmer, B., Lindberg, F., \& Thorsson, S. (2016). Intra-urban nocturnal cooling rates: Development and evaluation of the NOCRA model. Meteorological Applications, 23(3), 339-352. https://doi.org/ 10.1002/met.1558

Rall, E., Bieling, C., Zytynska, S., \& Haase, D. (2017). Exploring city-wide patterns of cultural ecosystem service perceptions and use. Ecological Indicators, 77, 80-95. https://doi.org/10.1016/j.ecolind.2017. 02.001

Rapoport, A. (1975). Toward a redefinition of density. Environment and Behavior, 7(2), 133-158. https:// doi.org/10.1177/001391657500700202

Staiger, H., Laschewski, G., \& Matzarakis, A. (2019). Selection of appropriate thermal indices for applications in human biometeorological studies. Atmosphere, 10(1), 18. https://doi.org/10.3390/atmos10010018
Street Tree Layer. (2018). Urban atlas: Street Tree Layer (STL) 2018. Copernicus. https://land.copernicus.eu/ local/urban-atlas/street-tree-layer-stl-2018

Thorsson, S., Rocklöv, J., Konarska, J., Lindberg, F., Holmer, B., Dousset, B., \& Rayner, D. (2014). Mean radiant temperature-A predictor of heat related mortality. Urban Climate, 10, 332-345. https://doi. org/10.1016/j.uclim.2014.01.004

Wolff, M., \& Haase, D. (2019). Mediating sustainability and liveability-Turning points of green space supply in European cities. Frontiers in Environmental Science, 7, Article 61. https://doi.org/10.3389/fenvs. 2019.00061

ZENSUS. (2011). Bevölkerung im 100m-Raster [Results for the population of the census of 9 May 2011 per grid cell]. https://www.zensus2011.de/DE/Home/ Aktuelles/DemografischeGrunddaten.html

\section{About the Authors}
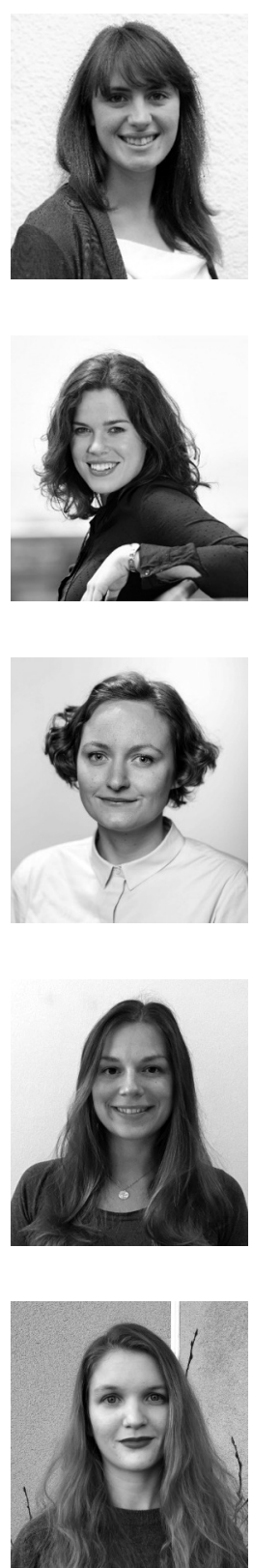

Julia Mittermüller is a research assistant in the Department of Sociology at Ludwig-MaximiliansUniversität, in Munich. She is pursuing a doctoral degree in environmental sociology and is especially interested in interdisciplinary research focusing on climate adaptation and sustainability, thermal comfort, and green infrastructure.

Sabrina Erlwein is a PhD candidate at the Chair for Strategic Landscape Planning and Management of the Technical University of Munich. She has studied geography and environmental planning in Marburg, Utrecht, and Munich, and has work experience as a city planner. Her research interest lies in investigating the possibilities of adapting the climate of growing cities through urban greenery and in interdisciplinary city planning.

Amelie Bauer is a research assistant in the Department of Sociology at Ludwig-Maximilians-Universität, in Munich. She has studied political science, sociology, and environmental studies. Research interests include environmental sociology, sufficiency and energy consumption in buildings, and urban development through interdisciplinary approaches.

Tatjana Trokai is a trained environmental engineer and planner and works at the Chair for Strategic Landscape Planning and Management, Technical University of Munich. She is interested in biodiversity, climate adaptation, and ecosystem services.

Sophie Duschinger is a researcher in a working group on environmental sociology at LudwigMaximilians-Universität, in Munich. She is particularly interested in energy consumption behaviour and thermal comfort. 


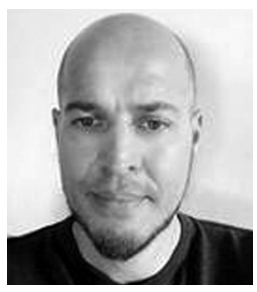

Michael Schönemann (Dipl.-Ing.) is a consultant at bifa Environmental institute. Incorporating geographic information systems, he provides information and counsel concerning local climate, natural resources, and the supply and usage of energy. The research studies and projects he is working on are focusing on sustainable development, climate protection, and adaptation. 